\title{
Reflexivity in Qualitative Social Research: Bridging the Gap between Theory and Practice with Alvin Gouldner's Reflexive Sociology
}

Reflexividad en la investigación social cualitativa: acortar la brecha entre teoría y práctica con la Sociología reflexiva, de Alvin Gouldner

Réflexivité dans la recherche sociale qualitative: en reduisant l'ecart entre la theorie et la pratique avec la Sociologie reflexive d'Alvin Gouldner

Reflexividade na pesquisa social qualitativa: encurtando a brecha entre teoria e prática com a Sociologia reflexiva de Alvin Gouldner

Received: JULY 30, 2014 / Accepted: SEPTEMBER 12, 2014 / Available online: DECEMBER 30, 2014

Find this article in http://magisinvestigacioneducacion.javeriana.edu.co/

doi: 10.11144/Javeriana.M7-14.RQSR

Written by ElISABETH SIMBÜRgeR

UnIVERSIDAD de VALPARAÍSO

Valparaíso, Chile

Abstract

elisabeth.simbuerger@uv.cl

Reflexivity has become a buzz-word in the social sciences. In this article I provide a critical discussion of the concept of reflexivity and its use in qualitative social research in educational contexts. I argue that one of the dilemmas of a lot of literature on reflexivity in the social sciences is the frequent absence of a discussion of how academics' aspirations to be reflexive in their research can be made accountable in academic practice. Based on the work of Alvin Gouldner I point to a different way of framing reflexivity in educational qualitative research that bridges the gap between theorising and practising reflexivity in the university and raises important questions about the implications of reflexivity or, of its lack. I thereby draw on extensive research on academic work and identity which I carried out in the UK and Chile based on qualitative interviews with academics. To conclude with, I suggest that discussions upon how to practise one's aspirations to be a reflexive academic should depart from a collective analysis of the current structures of marketisation in higher education and how they may constrain reflexive academic practice in the university.

\section{Key words plus}

Social Science, Scientific Methods, Interviews, Politics, University.

\section{Transference to practice}

Based on the work of Alvin Gouldner I point to a different way of framing reflexivity in educational qualitative research that bridges the gap between theorising and practising reflexivity in the university and raises important questions about the implications of reflexivity or, of its lack. I thereby draw on extensive research on academic work and identity which I carried out in the UK and Chile based on qualitative interviews with academics. To conclude with, I suggest that discussions upon how to practise one's aspirations to be a reflexive academic should depart from a collective analysis of the current structures of marketisation in higher education and how they may constrain reflexive academic practice in the university.

To cite this article / Para citar este artículo / Pour citer cet article / Para citar este artigo

Simbürger, E. (2014). Reflexivity in Qualitative Social Research: Bridging the Gap between Theory and Practice with Alvin Gouldner's Reflexive Sociology. magis, Revista Internacional de Investigación en Educación, 7(14), 55-68. 
Palabras clave descriptor

Ciencias sociales, métodos científicos, entrevistas, política, universidad.

\section{Resumen}

La reflexividad se ha puesto de moda en las Ciencias Sociales. En este artículo ofrezco una discusión crítica del concepto de reflexividad y su uso en la investigación social cualitativa en contextos educativos. Argumento que uno de los dilemas en una gran cantidad de literatura sobre la materia radica en la frecuente ausencia de discusión que permita entender en qué medida las aspiraciones reflexivas de los académicos en sus investigaciones pueden llevarse a cabo en la práctica académica. Con base en lo expuesto por Alvin Gouldner, el artículo plantea una manera diferente de enmarcar la reflexividad en la investigación cualitativa, de modo que sirva de puente entre la teoría y la reflexividad en la universidad; asimismo, formula preguntas importantes sobre las implicaciones de la reflexividad o de su ausencia. Con fundamento en entrevistas cualitativas a académicos, efectuadas en el Reino Unido y Chile, señalo una amplia investigación acerca de la labor académica y la identidad. Para concluir, sugiero que las discusiones sobre la puesta en práctica de las aspiraciones para ser un(a) académico(a) reflexivo(a) deben partir del análisis colectivo de las estructuras actuales de la mercantilización de la educación superior y la forma en que estas pueden limitar la práctica académica reflexiva en la universidad.
Transferencia a la práctica Con base en lo expuesto por Alvin Gouldner, el artículo propone una manera diferente de enmarcar la reflexividad en la investigación cualitativa, para que sirva de puente entre la teoría y la reflexividad en la universidad. Además, formula preguntas importantes sobre las implicaciones de la reflexividad o de su ausencia. Fundamentado en entrevistas cualitativas a académicos, efectuadas en el Reino Unido y Chile, señalo una amplia investigación acerca de la labor académica y la identidad. Para concluir, sugiero que las discusiones referentes a la puesta en práctica de las aspiraciones para ser un(a) académico(a) reflexivo(a) deben partir del análisis colectivo de las estructuras actuales de la mercantilización de la educación superior y la forma como pueden limitar la práctica académica reflexiva en la universidad.

\section{Mots clés} descripteur

Sciences sociales méthodes scientifiques entretiens, politique, université.

\section{Résumé}

La réflexivité est en vogue dans les Sciences Sociales. Dans cet article on expose un débat critique du concept de réflexivité et son usage dans la recherche sociale qualitative dans les domaines éducatifs. On argumente qu'un des dilemmes d'une grande quantité de littérature par rapport à la réflexivité dans les sciences sociales se trouve dans la fréquente absence de débat qui nous permet de comprendre dans quelle mesure les aspirations réflexives des académiques dans leurs recherches ont un impact dans la pratique académique. Ayant de base l'exposé par Alvin Gouldner, I'article montre une manière différente de cadrer la réflexivité dans la recherche qualitative pour qu'elle puise servir de pont entre la théorie et la réflexivité à l'Université, de la même manière on expose les questions importantes sur les implications de la réflexivité ou de son absence. Sur la base d'entretiens qualitatives avec des académiques, qui ont été réalisées au RoyaumeUni, et au Chili, on signale un ample recherche par rapport au travail académique et l'identité. Enfin on conseille que les longues discutions sur la mise en pratique des aspirations pour devenir un/une académique réflexive doivent partir de l'analyse collective des structures actuelles du marché de l'éducation supérieure et la façon dont ces structures peuvent limiter la pratique académique réflexive à l'Université.

\section{Transfert á la practique}

Ayant de base l'exposé par Alvin Gouldner, I'article montre une manière différente de cadrer la réflexivité dans la recherche qualitative à manière de pont entre la théorie et la réflexivité à l'Université, de la même manière on expose les questions importantes sur les implications de la réflexivité ou de son absence. Sur la base d'entretiens qualitatives avec des académiques, réalisées au RoyaumeUni et au Chili, on signale une ample recherche sur le travail académique et I'identité. Enfin, on conseille que les longues discutions sur la mise en pratique des aspirations pour devenir un/une académique réflexive doivent partir de l'analyse collective des structures actuelles du marché de l'éducation supérieure et la façon dont ces structures peuvent limiter la pratique académique réflexive à l'Université.

\section{Palavras-chave} descritor

Ciências sociais, métodos científicos, entrevistas, política, universidade.

\section{Resumo}

A reflexividade está de moda nas Ciências Sociais. Neste artigo ofereço uma discussão crítica do conceito de reflexividade e seu uso na pesquisa social qualitativa em contextos educativos. Argumento que um dos dilemas de uma grande quantidade de literatura sobre a reflexividade nas ciências sociais está radicado na frequente ausência de discussão que permita entender em que medida as aspirações reflexivas dos acadêmicos em suas pesquisas podem ser realizadas na prática acadêmica. Com base ao exposto por Alvin Gouldner, o artigo propõe uma maneira diferente de estabelecer a reflexividade na pesquisa qualitativa de maneira que sirva de ponte entre a teoria e a reflexividade na Universidade. Por outro lado propõe perguntas importantes sobre os envolvimentos da reflexividade ou, da ausência da mesma. Sobre a base de entrevistas qualitativas com acadêmicos, efetuadas no Reino Unido e no Chile, assinalo uma ampla pesquisa sobre o trabalho acadêmico e a identidade. Para concluir, sugiro que as discussões a respeito das aspirações para ser um(a) acadêmico(a) reflexivo(a) deveriam partir da análise coletiva das estruturas atuais da mercantilização da educação superior e da forma em que estas podem limitar a prática acadêmica reflexiva na universidade.

\section{Transferência à prática}

Com base ao exposto por Alvin Gouldner, o artigo propõe uma maneira diferente de enfocar a reflexividade na investigação qualitativa de maneira que sirva de ponte entre a teoria e a reflexividade na Universidade. Da mesma forma propõe perguntas importantes sobre os envolvimentos da reflexividade ou, da ausência da mesma. Sobre a base de entrevistas qualitativas com acadêmicos, efetuadas no Reino Unido e no Chile, assinalo uma ampla pesquisa sobre o trabalho acadêmico e a identidade. Para concluir, sugiro que as discussões a respeito das aspirações para ser um(a) acadêmico(a) reflexivo(a) deveriam partir da análise coletiva das estruturas atuais da mercantilização da educação superior e da forma em que estas podem limitar a prática acadêmica reflexiva na universidade. 


\section{Introduction}

Over the last few years, reflexivity has turned into a fashionable concept in the Social Sciences and Humanities. However, what comes under the banner of reflexivity is of varied nature. With reflexivity having been used in a rather inflationary way in the Social Sciences and Humanities, Martin O'Brien (1999) stated that the notion of reflexivity is used in an almost equally confusing manner as the concept of lifestyle, covering the areas of social theory, research ethics and qualitative social research more generally. The notion of reflexivity with regard to academic work and the research process can have meanings as diverse as: 1) A meta-analysis of the research process by both, the researcher and the researched with regard to how their socioeconomic status, gender, and general values in life may impinge on the research process and in particular on the interpretation; 2) reflexivity as a defining characteristic of all human action and as a condition of modernity where thought and action are always related back to each other (Giddens, 1990), and 3.) the idea of reflexivity in academic work as the combination of reflexive aspirations and reflexivity in practice in all dimensions of academic life, holding academics accountable to their claim thereby departing from the premise that the scholarly, personal and political dimensions of academic work can never be seen in separation from each other (Gouldner, 1970)1.

When doing research in education in and around the university, reflexivity becomes a fundamental issue that needs to be considered. One of the dilemmas of doing educational research is that for being part of what we are researching, we become automatically entangled with the subject and object of our research. We are thus confronted with the paradox of being inside and outside of our research object at the same time (Bourdieu, 1993; Bourdieu \& Wacquant, 1992). A variety of authors has tried to come to terms with this paradox. Whereas Pierre Bourdieu and Loic Wacquant tried to master the dichotomy of being inside and outside of one's research by means of participant observation, feminists discuss introspection into one's own intellectual biography as a fruitful resource for constructively dealing with the subject-object relationship and subsequently leave this dichotomy behind altogether (Stanley \& Wise, 1990).

Over the last ten years, in my own research on academic work and academic identity in both the $U^{2}$ and Chile $^{3}$ the questions of how to en-

1 Liz Stanley summarised different forms of reflexivity: "Steve Woolgar (1988) has termed 'constitutive reflexivity' and 'benign introspection'. Bruno Latour (1988) has referred to 'meta-reflexivity' and 'infra-reflexivity'. Stanley (1990) has dubbed 'descriptive reflexivity' and 'analytical reflexivity'. Pierre Bourdieu (1992) has discussed it as 'participant objectification' and 'biography'. Tim May (1999) has called it 'endogamous reflexivity' and 'referential reflexivity'. Scott Lash (1994) has referred to it as 'cognitive reflexivity', 'aesthetic reflexivity' and 'hermeneutic reflexivity" (Stanley, 2000, p. 71). In line with Stanley, it is important to note that these forms of reflexivity are not entirely distinct from each other

2 My doctoral research was a theoretical and empirical investigation of sociologists and sociology in the UK. The research aimed to inquire how sociologists related to the discipline what they define as its key elements and how they negotiate these aspirations in the current contexts of higher education driven by public funding cuts and quality assurance regimes (Simbürger, 2009). The research was conducted in thirty qualitative interviews with sociologists in ten Sociology Departments in England following a matrix of age, gender, position, research interest and type of university. In a related study - "Sociologists Talking" - I carried out another 25 interviews with sociologists. The results of this research were presented in an audiovisual exhibition on sociology as a profession together with Cath Lambert (Back, 2008)

3 The second comprehensive research project this paper draws on is a three year long project on the construction of neoliberal discourse about academic work in Chile (Fondecyt 11110528; 2012-2015). Based on higher education policy discourse analysis between 1990
Article description | Descripción del artículo | Description de I'article | Artigo descrição

This paper of reflection is based on research. In this article I provide a critical discussion of the concept of reflexivity and its use in qualitative social research in educational contexts. I argue that one of the dilemmas of a lot of literature on reflexivity in the social sciences is the frequent absence of a discussion of how academics' aspirations to be reflexive in their research can be made accountable in academic practice. Based on the work of Alvin Gouldner I point to a different way of framing reflexivity in educational qualitative research that bridges the gap between theorising and practising reflexivity in the university and raises important questions about the implications of reflexivity or, of its lack. Work on this article was supported by the Chilean National Funding Agency Conicyt and the research grants Fondecyt Iniciacion 11110528 and Fondecyt Regular 1141271. 
counter the challenge of being inside and outside at the same time were fundamental ones. In my research I am interested in how academics perceive themselves and how they practise and try to negotiate academic identities at universities, considering constraining contexts in global higher education such as public funding cuts, quality assurance and the pressure to publish (Simbürger, 2009; 2010). I am further interested in how academics as well as higher education and higher education policy contribute to the construction of neoliberal discourse around academic work. When speaking to academics about their identities and about their academic practice, one encounters many contradictions (Guzmán-Valenzuela \& Barnett, 2013). Academics don't always act according to their aspirations. Who comes across as very critical on the page, may be devaluing the importance of teaching and rather focus on higher valued research and publications in order to make a career (Simbürger, 2010; Smith, 2011). This is what Lisa Lucas termed as "academics playing the game" (Lucas, 2006).

In a nutshell, the challenge of researching academics is twofold. On the one hand, researching academics, one of the key questions is how to deal with the paradox of being inside and outside at the same time. On the other hand, the question of the meaning of reflexivity of academic interviewees emerges. Having the chance to elaborate on one's own academic work and thus deliberating a meta-perspective can be an enrichening experience for academics as it gives them the possibility to gain some outside perspective on their own work and may provide them with the chance to evaluate their own endeavours (Dressel \& Langreiter, 2003; Mauthner \& Doucet, 2003). Many of my interviewees told me that the interview had given them the chance to think about themselves as academics in a more systematic manner for the very first time. They enjoyed being interviewed and I could also see that some of them clearly benefited from the reflections that evolved throughout the interview. Hence, interviewing could be understood as a social process that has the latent function of enhancing a reflexive mindset among interviewees. Yet, researching academics about their academic identity and their work, my interest was also geared towards connecting the experiences of academics back to their initial aspirations as academics. As a consequence, I was in need of a conceptual framework that captures both theoretical and practical issues of reflexivity. This is what this article is about.

First of all, I will analyse the relevant literature in social research methods and social theory with regard to their framing of reflexivity. Secondly, I will introduce Alvin Gouldner's Reflexive Sociology as a possible alternative to approaches that do not bridge the gap between theorising reflexivity and reflexive academic practice. Thirdly, drawing on my own research I will show how Gouldner's Reflexive Sociology can evolve in practice. Some of my respondents' narratives will serve as exemplifiers of what Peter Sloterdijk calls modern cynicism (Sloterdijk, 1984). Finally, from the lessons learned from empirical research on reflexivity, I will provide some practical advice for dealing with reflexivity in qualitative educational research in current contexts of marketisation in higher education.

and 2010 on the one hand and in total 70 qualitative interviews with fulltime, part time and precariously employed academics from sociology, education and biology based at different types of universities throughout the country, the project seeks to understand how neoliberal discourse around academic work was implemented over time and how academics themselves understand and negotiate their identities in current contexts. 


\section{Reflexivity: variations on a theme}

When I started out doing research on academic identity and academic work I needed to define what reflexivity was about. Yet, the challenge consisted in finding a concept that not only served my theoretical or methodological purposes, but covered all grounds. In the following I will analyse how the relevant literature from social research methods and social theory frames reflexivity and to what extent these concepts could be useful for studying academic identities and academic practice.

\section{Reflexivity and methodology}

From the 1990s onwards reflexivity has become a major topic in research methodology. This is reflected in numerous contributions to research methodology and attempts to ingrain the role of the researcher in the process of research and writing up in a so-called reflexive way (Alvesson \& Skoeldberg, 2000; Davies, 2008; Dressel \& Langreiter, 2003; Mauthner \& Doucet, 2003). These discussions of reflexivity mostly revolve around qualitative methods, whereas quantitative methods and reflexivity issues seem to be associated less frequently (Ryan \& Golden, 2006). What is at the core of these discussions is an analysis of how the relationship between researcher and researched unfolds in the research situation and impacts on the analysis. Yet, whilst these contributions are useful, they mostly emphasise only specific aspects of academic work - namely, the research process and the process of writing - whilst other areas remain untouched. Without doubt, one of the most important achievements of reflexive sociology projects of the last thirty years is the institutionalisation of research ethics. Sociologists' thinking about ethical limitations and potential of their research suggests that they acknowledge having social responsibility as researchers, both in the way they conduct it as well as in how they communicate their results to the public (Bryman, 2008). Yet, whilst this is institutionally reflected in the implementation of ethical codes and ethics committees (British Sociological Association, 2002; Dench, Iphofen \& Huws, 2004), research ethics in its current practice in places resembles a manifestation of political correctness and seems to become overly regulated (Richardson \& McMullan, 2007; Vujakovic \& Bullard, 2001).

Another important distinction in relation to reflexivity is hinted as between the role of the researcher as interviewer and the role of the researcher as writer. The increase in publications on researchers and their (auto)biographies, as well as the more frequent employment of auto-biographic modes of writing, can be seen as a result of the reflexive turn. With regard to autobiographical writing, sociologists have been trying to make sense of academic activity from different perspectives, focusing on sociologists and their autobiographical accounts in particular countries - mostly the US (Berger, 1990; Glassner \& Hertz, 2003) — and specific periods of time, such as the development of sociology after WWII (Fleck, 1996), the processes of becoming a sociologist during 1968 and sociological activity at the time (Sica \& Turner, 2005). Whilst some of these contributions relate the actor and her work to a specific period of time and space (Fleck, 1996; Sica \& Turner, 2005), more often than not, autobiographical collections on academics - in this case, sociologists - do not add much to a thorough analysis of academic activity and the development of social thought and practice. Autobiographies frequently do not go beyond a narcissticallymotivated analysis of one's own work, and remain limited in their outlook. Being a prototype of this kind, Homans notes in the preface to his book 
Coming to my senses. The autobiography of a sociologist that one of the reasons why he wrote his autobiography is that "[...] I enjoy writing, especially about my favorite subject, myself" (Homans, 1984).

Within the context of methodological changes, autobiographical writing has experienced a revival and can be considered as another dimension through which we can observe rising sensitivity for reflexivity issues (Cosslett, Lury \& Summerfield, 2000; Stanley, 1992). Autobiographies or autobiographical writing seem to be a first step towards acknowledging the intertwining of history and our lives, and therefore our research agendas, rather than seeing academic work as an ahistorical endeavour. It means that the theories we produce are an outcome of our social lives and political contexts, and are directly shaped by them. Yet, hardly ever can it be seen what kind of substantive sociological insight an increased process of undressing one's inner feelings about one's research and the connection to one's biography amount to. It sometimes seems that methodology becomes another stage for the presentation of the self and a second-order expression for the individualisation processes of society that have finally reached academia. After all, what is missing in these attempts at reflexivity are mechanisms by which these confessions and aspirations can be held accountable on the dimension of academic practice.

\section{Reflexivity in social theory}

In the following, I will discuss how reflexivity has been framed in contemporary social theory. Pierre Bourdieu (1993) considers a sociology of sociology as a precondition for any kind of sociological pursuit rather than as one specialism among others. For Bourdieu, self-analysis reveals the relationship between intellectual ideas and cultural and economic structures. Bourdieu has extensively done this in his work, analysing French universities and the functions of the faculty in the 1960s (Bourdieu, 1988). However, Bourdieu's leaving aside the academic's — in that case the sociologist's - potentially transformative role raises the question of whether his reflexivity project was ultimately carried out for its own sake, although this also seems to be at odds with Bourdieu's mission to prevent the sociology of sociology from becoming an end in itself (Adkins, 2003).

Moving to the UK, I would like to shed light on the work of Anthony Giddens and Margaret Archer in its potential suitability as theoretical frameworks for my endeavours. Giddens' intellectual efforts concerning reflexivity culminated in publications such as Reflexive Modernisation together with Ulrich Beck and Scott Lash in the 1990s (Beck, Giddens \& Lash, 1994). Within this triad of "reflexive sociologists", his notion of reflexive modernisation became a vanguard for social theory in the 1990s. Yet, the foundations for this were set much earlier in New Rules of Sociological Method (Giddens, 1976). Whereas reflexivity existed in pre-modern times, modernity can be characterised as a period where reflection reaches a full level, as reflection also includes the level of reflection itself. In this sense, Giddens uses the words reflection and reflexivity in an interchangeable manner ${ }^{4}$. According to Giddens, thought and action are thereby always related back to each other with reflexivity being a defining characteristic of all human action and as a condition of modernity (Giddens, 1990). Within that, sociology would take a "pivotal position" that derives "from its role as the most generalised type of reflection upon modern social life" (Giddens, 1990, p. 41). As O'Brien counters, the different ways in which reflexiv-

4 In contrast to Giddens, Gouldner only employs the notion of reflexivity. 
ity is used in Giddens' work give rise to questions about the relationship between reflexivity, rationality and agency. Mouzelis (1999) conceives Giddens' notion of reflexivity as "over activistic", suggesting that subjects would constantly find themselves in "meansends situations", making decisions" (p. 85). Giddens seems to see reflexivity as a consequence of the times we live in, rather than as a conscious process that we need to seek to engage in. Taking this further for our investigations into the self-understanding of academics and their work, in a Giddensian world unreflexive academics would be a logical impossibility.

With reflexivity being considered a default mode of being human, Margret Archer's preoccupation with reflexivity raises problems similar to those associated with Giddens. In her investigations on the connection between structure and agency, Archer developed the idea of reflexivity as the necessary mediation between structure and agency (Archer, 2003; 2007). For Archer (2003), reflexivity is accomplished by the internal conversation:

This is the modality through which reflexivity towards self, society and the relationship between them is exercised. In itself it entails just such things as articulating to ourselves where we are placed, ascertaining where our interests lie and adumbrating schemes of future action (p. 9).

Since the mediation between structure and agency is a precondition of being human, we are reflexive by our human nature. Taking this further to our case of academic activity, this would mean that reflexivity runs through all our activities. Based on empirical research, Archer develops a typology of reflexivity that differ from each other in the degree to which people use internal conversation as a way of evaluating their practices. The type of reflexive that comes closest to what we are interested in, namely academic activity, is the meta-reflexive (Archer, 2007). Yet, a possible challenge of applying Archer's and Giddens' notion of reflexivity to a qualitative research project that aims to relate academics' academic practice back to their reflexive aspirations consists in the fact that their notions of reflexivity do not specify what reflexivity really involves and, in the case of Archer, what the consequences of not having an internal conversation are.

\section{Alvin Gouldner's Reflexive Sociology as a panacea for one-dimensional approaches to reflexivity}

In the following, I will discuss Alvin Gouldner's Reflexive Sociology as possible panacea for approaches to reflexivity that either deal with a theoretical dimension of reflexivity, yet not relating this back to academic practice or approaches that are mostly concerned with reflexivity as a methodological issue, leaving aside a more holistic understanding of the role of the academic that connects scholarly, personal and political dimensions. Alvin Gouldner, who was trained at Columbia University and supervised by Robert Merton, spent the first half of his career occupied with professional sociology, before devoting himself to the sociology of knowledge and an analysis of his own discipline (Calhoun \& VanAntwerpen, 2007; Chriss, 1999). Critiquing Parsonian Functionalism, Gouldner exposed value-free sociology as a myth and argued that in at least three areas - the selection of problems, the preferences for certain hypotheses and the choice of certain conceptual schemes - the intrusion of one's personal values is unavoidable (Gouldner, 1970). His main argument was that even in a so-called value-free sociology, values are expressed; but instead of doing this overtly and consciously, this would happen covertly by associating the existing system with goodness (Gouldner, 1973, p. 485). Segregating personal from professional roles would also have implications for how theory relates to practice, disregarding the mutual connectedness of facts and values.

For Gouldner — similarly to Bourdieu years later- making ourselves and sociology the subjects of scrutiny would constitute the precondition for gaining knowledge of the outside world (Gouldner, 1970). Like C. Wright Mills, Gouldner suggested that being a sociologist is a life-encompassing activity that cannot be discarded at the doors of a university. The process of awareness of ourselves in our totality in relation to our research and the outside world is at the core of Gouldner's Reflexive Sociology program. What makes his work so distinctive is that it is an epistemological position with practical and political implications ${ }^{5}$. For him, Reflexive Sociology:

[It] is characterized, rather, by the relationship it establishes between being a sociologist and being a person, between the role and the man performing it. A Reflexive Sociology embodies a critique of the conventional conception of segregated scholarly roles and has a vision of an alternative. It aims at transforming the sociologist's relation to his work (Gouldner, 1970, p. 495).

5 It is important to note that just as being reflexive does not necessarily imply having a critical agenda in mind, not all claims of critique are necessarily based on reflexivity. For Gouldner, however, reflexivity and critique need to be thought of together, and only in this togetherness can they qualify for being labelled as reflexive sociological activity. 
Coming from Marxist social theory himself, Gouldner accomplished this in his analysis of the growing convergence between Marxism and Functionalism. He accused Marxist sociologists of being in a static relationship with their theory, of not living up to their strong theoretical claims of critique and not questioning the foundations of their thought (Gouldner, 1970). In this respect, even the most critical and reflexive intellectual approaches should not be exempted from a critical analysis as to whether their "practitioners" in the university live up to their critical intentions. Taking this further to our purposes of qualitative research in education, it becomes clear that Gouldner asks for an approach to reflexivity in which reflexive aspirations can be held accountable on the dimension of academic practice. Gouldner's understanding of reflexivity radically differs from the other notions of reflexivity that I introduced earlier. What makes Gouldner's work so distinctive and suitable for my purposes of researching the self-understanding of academics is that it is an epistemological position with practical and political implications. Gouldner's major credo for critical self-inquiry is an open invitation to equally critique his work and not to declare it as the new solution to all possible dilemmas with regard to reflexivity in qualitative research in educational contexts ${ }^{6}$.

\section{Researching academics}

In the following, I would like to discuss how I translated a theoretical reflexivity approach into empirical research and thereby bridged the frequent gap between theoretical and practical considerations with regard to reflexivity. In my qualitative research projects in educational research in and around the university I have been applying Gouldner's Reflexive Sociology and translated it into my research methodology. I will discuss a variety of reflexivity issues that came up in the course of interviewing academics about their selfunderstanding and their academic work both in the UK and in Chile. Finally, I will demonstrate how my own positioning as a researcher impacted on my research.

In both projects, the construction of semi-structured interview schedules was informed by my theoretical framework. However, as Gouldner himself did not have anything to say about "research methods', the methodology-oriented reader may wish to gain some more specific information as to how this approach could be phrased within the genre of research

6 With Michael Burawoy's 2004 Presidential Address to the American Sociological Association 'For Public Sociology', we encounter a more current engagement with the ideas of Alvin Gouldner and their relevance to academic life and in particular sociologists in current times (Burawoy, 2005). methodology literature. What comes closest to what I have just outlined is Alvesson's \& Skoeldberg's Reflexive Methodology (2000). Alvesson and Skoeldberg argue that the often technical use of qualitative methods indicates that qualitative work becomes a process that is disentangled from the theories previously used. The focus on "data collection and processing" in most qualitative methodological theories would be unreflective. Instead, they suggest that a fundamentally hermeneutic element should permeate the research process at all stages. Hence, interpretation rather than the representation of reality on the basis of collected data should become the central element.

\section{Interviewing academics: (methodological) reflexivity is in the air!}

In the following I would like to describe what happened before, during and after the interview, including the little conversations. I soon realised that the email correspondence with potential respondents prior to interviews also was a rich documentation in itself of the relationships between my informants and myself. Some people wanted to have more detailed information on why I had selected them, the theoretical background of the study and how I would ensure anonymity and confidentiality. With some respondents there were hints of a small discourse on methodological issues. The most remarkable case was that of one respondent who asked me to have a look at the interview schedule beforehand and then sparked a discussion on how this might have an impact on the interview situation. Others shared their skepticism about academic work and their discipline with me and admitted to finding themselves in a crisis with academic work more generally. Whenever academics replied to my emails negatively, they always gave a detailed account of why they thought of themselves as not being the right person for my interviews.

Some respondents were more articulate than others. One could tell from their narratives and how they presented their reflections whether they had thought about questions in relation to their lives as academics before. One of the biggest surprises was that in contrast to what I had expected, most respondents did not end up in a meta-discourse on their discipline. Rather, they provided a very personal approach to their work and subject area. This started with their telling me how they came to the discipline. The personal dimension became even more evident when I asked them what led them to work in their particular research area. This resonated with Liz Stanley's and Sue Wise's argument of the Self affecting every aspect of research - from the choice of project to the presentation of findings (Stanley \& Wise, 1993). 
Respondents said that they don't mind my recording the interview; they asked whether I had double-checked that the voice recorder was working, on this occasion recounting a little anecdote about their own empirical research. They asked whether I would like to have a drink and which chair I would like to sit on. I could sit on this chair, one of my respondents told me whilst pointing to the chair and explaining that we would then sit on equal levels. It was evident that we had a lot in common. Indeed, it was academics talking, them telling me a story and me on the other hand asking and listening. This was when it was crystal-clear that my counterpart was a social scientist like myself, well aware of the interview situation and all of its implications (Mauthner \& Doucet, 2003).

Having said that, this apparent reflexivity with regard to the interview situation was hardly ever present throughout the entire interview. As much as they were wary of my being the interviewer and their being the interviewee, as the interview carried on, this hyper-reflexive dynamic with regard to the interview situation was no longer omnipresent. During the interview, I mostly perceived my respondents as being thoroughly occupied with articulating their thoughts. Occasionally, I asked respondents after the interview how they had experienced it. Many of them told me that the interview had given them the chance to think about themselves as academics in a more systematic manner for the very first time. They enjoyed being interviewed and I could also see that some of them clearly benefited from the reflections that evolved throughout the interview. One respondent even took notes of her own ideas while we were talking. In this respect the interview was a more mutual relationship and, I would assume, an equally rewarding experience for my respondents.

Making sense of academics' narratives: reflexivity unfolded

The richness of Gouldner's Reflexive Sociology lends itself to a way of thinking by means of which the empirical material can be made sense of, framing academia as an activity that can only be understood if we see history, social theory, the academic and academic practice in relation to each other. This involved interweaving my respondents' views with a structural level of understanding, shedding more light on relevant issues of politics and history. Similarly, Alvesson and Skoeldberg (2000) particularly emphasise the significance of the political, economical, historical, social and personal spheres that form a comprehensive basis against which empirical data can be understood.

In my past and current research into the self-understanding of academics in the UK and in Chile I have been aiming to go beyond a mere illustration of academics' intersecting biographies, research agendas and general complaints about academia. Rather, leading academics' narratives about their practices back to their initial disciplinary aspirations, I wanted to make academics accountable both to their own claims as well as to what they consider to be the vocational calling of being an academic. By and large, my respondents reflected on their own difficulties of living and practising one's academic ideals in a global environment of higher education that is driven by publication output as a commodity, quality assurance, league tables and external funding (Sachs, 2001). Some respondents admitted that academics themselves are complicit in undermining critique in the university.

In the following, I would like to illustrate these tensions between theory and practice with two selected quotes from my research. Reluctance 
emerged when my respondents talked about their own practices in relation to their sociological aspirations they had enthusiastically uttered earlier. Stephen explains that this is a result of the paradox of being inside the thing one is trying to understand.

I think one of the ironies or paradoxes — not just of sociology, but of the humanities - is that those people who are the writers and the listeners are inside the thing they are trying to understand. And like most people they are, to different degrees, strangers to themselves. And I have always thought that the project of sociological practice is not only to think about the way others are caught in worlds that are constructed by ideas and sorts of understandings but equally how the analyst, the writer is caught within that track of being a stranger to oneself (Stephen, 44, professor, University of London College).

Disappointment about our failure as academics in living up to the promises of being critical and reflexive in our own surroundings can be found in many of my interviews. According to Celine's observations, sociologists' social conduct often strikingly deviates from the strong and radical claims they make in their written work.

[O]ne of the biggest shocks I found, I learned to accept it now, was people write about really radical things. But they act so differently. You know, they act in very problematic terms. You know they write about race and gender but they replicate certain kinds of thinking that are problematic [...]. So [there is a] gap between what's on the page and the social interaction they create [...]. Now I am not surprised when I meet people who on the page sound really radical but if you look at how they operate. I mean, the careerism of academia is rife, you know. It's rife. People are so strategic (Celine, 40, senior lecturer, University of London College).

Celine's thoughts about sociologists who "write about really radical things" but "act in very problematic terms" resonates with Alvin Gouldner's analysis of sociologists often not coming true to their initial academic aspirations.

\section{When nothing makes sense: reflexivity and cynicism}

So far I have discussed the disappointed reactions of some sociologists who think that sociology has failed in living up to its own expectations. However, the most striking cases were those respondents who are aware of their contradictions but nevertheless maintain their conduct, with a "reflexive" mind set. In the light of compromised academic practice I would finally like to discuss whether being reflexive of one's conditions and potentially one's deficiencies can be seen as a sufficient response to failure. Throughout the interview, Lydia, a young lecturer from a 1960s UK university, has elaborated on her own contradictions of on the one hand wishing to contribute to more knowledge as a sociologist in the public domain, whilst on the other hand having extreme reservations against it. Finally, I wanted to challenge Lydia by asking her whom she ultimately produces knowledge for. Her answer to my question is surprisingly open: not only does she admit that she produces knowledge for an academic audience, but she also makes explicit another motivation for doing that, namely, to make herself a name and a career. 
I am producing research for an academic audience that I think people might be interested in reading. Because I want to make myself a name and want to make a career [...]. It would be ridiculous of me to say I think that it is really important that we communicate widely and that I am doing it because I want my work to reach the public and still find it so difficult to try that. And I think that there are so few sociologists who do step in and communicate with the public and far more who say they do. You have to be consistent in your behaviour (Lydia, 32, lecturer, 60s university).

Lydia interprets her own answer as consistent in the sense that she would at least not claim to be contributing to social change any longer. Whilst this can be seen as a very honest answer in that Lydia acknowledges her own difficulties in reaching out to nonacademic publics in alternative ways, her statement also encompasses some troubling elements. Initially, Lydia was one of those respondents who were especially keen on pointing out sociology's distinctive and particular role as critical in society as opposed to other disciplines, such as economics. However, the importance of the critical role of sociology in her narrative gets quickly overshadowed by how she justifies not to live up to her initial aspirations.

Lydia's response also needs to be seen in the context of the discourse about reflexivity within academia. It seems that academia becomes another stage for the presentation of the self and a second-order expression for the individualisation processes of society that have finally reached academia and academics. After all, what is missing in these attempts of reflexivity about one's research and one's position as an academic - as we could see in the case of Lydia - are mechanisms by which these confessions can be held accountable on the dimension of academic practice. This may be an expression of what Gouldner wanted to prevent when he mentioned that radical or critical sociology should not become another sub-sociology (Gouldner, 1970). Dismantling current self-reflexivity discourses, elements emerge that cannot be labelled as anything other than narcissistic. Even taking the most defeatist attitude towards sociology and its core principles still seems to be legitimate under the pretext of reflexivity. What needs to be raised is whether the kind of hyper-sensitive posturing about one's failure as an academic and the consequent revision of one's professional claims, ultimately ending up in their deletion, is in any way a preferable academic conduct compared to a complete lack of awareness of one's contradictions. What is left, if we do not put any real effort into reiterating our academic claims but start to make a process of collective psychological undressing a new form of critique and reflexivity?
The German philosopher Peter Sloterdijk developed his thesis of modern cynical reason, providing a direct critique of the enlightenment, but in particular a critique of what he sees as the self-defeating nature of critical theory. Long before the heyday of the marketisation of Higher Education and its consequences, Sloterdijk seems to have captured the phenomenon that has become part of our everyday lives in academia, a cynical way of living and approaching the world. In fact, according to Sloterdijk (1984), cynicism seems to have replaced critique:

Critique, in any sense of the word, is experiencing gloomy days. Once again a period of pseudo-critique has begun, in which critical stances are subordinated to professional roles. Criticism with limited liability, petty enlightenment as a factor in success -a stance at the junction of new conformisms and old ambitions. Such a critique realizes that having success is a long way from having an effect. It writes brilliantly but in vain, and that can be heard through everything (p. xxxvi).

This can best be seen with some of my respondents, who seem to consider - whether deliberately or not- reflexivity (or cynicism, as Sloterdijk would call it) as the panacea for the loss of critique. Taking Sloterdijk further, Lydia's reflection or better her outing upon her "failure" almost counts as a critical and reflexive success and as a substitute for a continued conversation upon what to do with critique in the light of difficulties. However, it also constitutes the endpoint of discourse rather than its beginning and the preoccupation of how we could then reformulate and convey critique under these circumstances. Lydia is certainly not alone according to Sloterdijk (1984):

Modern cynics are no longer outsiders. Modern cynics are integrated, asocial characters who, on the score of subliminal illusionlessness, are a match for any hippie [...]. Psychologically, present-day cynics can be understood as borderline melancholics, who can keep their symptoms of depression under control and can remain more or less able to work. Indeed, this is the essential point in modern cynicism: the ability of its bearers to work -in spite of anything that might happen, and specially, after anything that might happen. For cynics are not dumb (stupid), and every now and then they certainly see the nothingness to which everything leads. Their psychic apparatus has become elastic enough to incorporate as a survival factor a permanent doubt about their own activities. They know what they are doing, but they do it because, in the short run, the force of circumstances and the instinct for self-preservation 
are speaking the same language, and they are telling them that it has to be so (p. 4ff).

As a consequence of these elaborations upon the cynic use of reflexivity one may question the feasibility of having aspirations to be reflexive in the university and to practise a vocational calling. Yet, rather than maintaining a pessimistic outlook, it may be more constructive to discuss the feasibility of reflexive academic practice (in the plurality of its meaning) in the light of a critical analysis of the current conditions of higher education and the factors that may both facilitate and constrain reflexive academic practice In fact, current politics of the formation of university teachers and the marketisation of knowledge as well as the dualism of research and teaching and the unequal weight that is put on both, are constraining factors for reflexive academic practice. With regard to the current conditions of marketisation, public funding cuts, assessment and quality assurance in Higher Education, the political dimension of reflexivity becomes even more important. This is not a missionary call for simple politics in the streets. Rather, one's vocational calling as an academic can translate into a variety of ways such as writing against the cuts, teaching critical thinkers, showing solidarity for one's co-workers instead of "playing the game" and speaking up in public when necessary.

\section{Reflexivity revisited: lessons for qualitative research in education}

In the course of this article I have shown the many potential pitfalls of a fashionable concept. Having analysed literature on reflexivity from research methodology and social theory I demonstrated that reflexivity can only develop its full potential in qualitative social research if we go beyond reflexivity on a theoretical or methodological level. I discussed Alvin Gouldner's Reflexive Sociology and identified it as a fruitful approach that theorises the relationship between theory and practice and makes academics and their practice accountable to their initial aspirations (Gouldner, 1970). At the heart of my research was the interest to capture one of the central dilemmas of qualitative social research in education, the tensions between the claims academics make about themselves and their academic practice. By leading academics' narratives about their practices back to their initial disciplinary aspirations, I wanted to make academics accountable both to their own claims as well as to what they consider to be the vocational calling of being an academic. While the specificities of my research into academic identity and academic practice need to be taken into account, my warning to educational practitioners who want to work reflexively in their qualitative research in educational contexts can be summarised as follows: Unless you fancy narcissistic events of academic speech and writing, make sure reflexivity accompanies your research throughout all phases, covering theory and methodology and employing a notion of reflexivity that includes a more political dimension of academic work and promotes an active role of the academic. Neither is it practically possible nor desirable to try to relate all academic practice back to academics' initial inspirations. Yet, in times of hyper-reflexivity enriching the concept of reflexivity with a political dimension seems to be a necessary step forward towards an understanding of academic work as an intrinsically political activity.

\section{About the author}

Elisabeth Simbürger is a senior lecturer at the Institute of Sociology at the Universidad de Valparaíso, Chile. Her work focuses on the politics of knowledge and knowledge production in higher education, with a particular focus on the Social Sciences and Humanities and the epistemological transformation of sociology as a discipline as a result of historical, political and economic change.

\section{References}

Adkins, L. (2003). Reflexivity: Freedom or Habit of Gender? Theory, Culture \& Society, 20(6), 21-42.

Alvesson, M., \& Sköldberg, K. (2000). Reflexive Methodology. New Vistas for Qualitative Research. London: SAGE.

Archer, M. (2003). Structure, Agency and the Internal Conversation. Cambridge: Cambridge University Press.

Archer, M. (2007). Making our Way through the World: Human Reflexivity and Social Mobility. Cambridge: Cambridge University Press.

Back, L. (2008). Sociologists Talking. Sociological Research Online, 13(6). Retrieved from http://www. socresonline.org.uk/13/6/3.html

Beck, U., Giddens, A., \& Lash, S. (1994). Reflexive Modernization. Politics, Tradition and Aesthetics in the Modern Social Order. Cambridge: Polity Press.

Berger, B. M. (ed.). (1990). Authors of their own Lives. Intellectual Autobiographies by Twenty American Sociologists. Berkeley: University of California Press.

Bourdieu, P. (1988). Homo Academicus. London: Polity Press.

Bourdieu, P. (1993). Sociology in Question. London: SAGE.

Bourdieu, P., \& Wacquant, L. J. D. (1992). An Invitation to Reflexive Sociology. Chicago: University of Chicago. 
British Sociological Association. (2002). Statement of Ethical Practice. Retrieved from http://www.britsoc.co.uk/about/equality/statement-ofethical-practice.aspx

Bryman, A. (2008). Social Research Methods (3rd ed.). Oxford: Oxford University Press.

Burawoy, M. (2005). 2004 American Sociological Association Presidential Address: For Public Sociology. The British Journal of Sociology, 56(2), 259-294.

Calhoun, C., \& VanAntwerpen, J. (2007). Orthodoxy, Heterodoxy, and Hierarchy: "Mainstream" Sociology and Its Challengers. In Calhoun, C. (ed.) Sociology in America. A History. Chicago: Chicago University Press.

Chriss, J. J. (1999). Alvin W. Gouldner: Sociologist and Outlaw Marxist. Alderslot: Ashgate.

Cosslett, T., Lury, C., \& Summerfield, P. (eds.). (2000). Feminism and Autobiography: Texts, Theories, Methods. London: Routledge.

Davies, C. A. (2008). Reflexive Ethnography: A Guide to Researching Selves and Others. (2nd ed.). London: Routledge.

Dench, S., Iphofen, R. \& Huws, U. (2004). An EU Code of Ethics for SocioEconomic Research. Brighton: Institute for Employment Studies.

Dressel, G., \& Langreiter, N. (2003). When "We Ourselves" Become Our Own Field of Research. Forum: Qualitative Social Research, 4(2). Retrieved from http://www.qualitative-research.net/fqs-texte/2-03/203dresselangreiter-e.htm

Fleck, C. (ed.) (1996). Wege zur Soziologie nach 1945. Autobiographische Notizen. Opladen: Leske+Budrich.

Giddens, A. (1976). New Rules of Sociological Method: A Positive Critique of Interpretative Sociologies. London: Hutchinson.

Giddens, A. (1990). The Consequences of Modernity. Cambridge: Polity Press.

Glassner, B., \& Hertz, R. (eds.) (2003). Our Studies, Ourselves. Sociologists' Lives and Work. Oxford: Oxford University Press.

Gouldner, A. W. (1970). The Coming Crisis of Western Sociology. London: Heinemann.

Gouldner, A. W. (1973). For Sociology: Renewal and Critique in Sociology Today. London: Allen Lane.

Guzmán-Valenzuela, C., \& Barnett, R. (2013). Academic Fragilities in a Marketized Age: the Case of Chile. British Journal of Educational Studies, 61(2), 1-18.

Homans, G. C. (1984). Coming to My Senses. The Autobiography of a Sociologist. New Brunswick: Transaction Books.

Lucas, L. (2006). The Research Game in Academic Life. Maidenhead: Open University Press.

Mauthner, N. S., \& Doucet, A. (2003). Reflexive Accounts and Accounts of Reflexivity in Qualitative Data Analysis. Sociology, 37(3), 413-431.

Mouzelis, N. (1999). Exploring Post-traditional Orders: Individual Reflexivity, "Pure Relations" and Duality of Structure. In O' Brien, M., Penna, S., \& Hay, C. (eds.) Theorising Modernity. Reflexivity. Environment and Identity in Giddens' Social Theory. London: Longman.

O'Brien, M. (1999). Theorising Modernity. Reflexivity, Identity and Environment in Giddens' Social Theory. In O' Brien, M., Penna, S., \& Hay, C. (eds.) Theorising Modernity. Reflexivity. Environment and Identity in Giddens' Social Theory. London: Longman.

Richardson, S., \& McMullan, M. (2007). Research Ethics in the UK: What Can Sociology Learn from Health? Sociology, 41(6), 1115-1132. 
Ryan, L., \& Golden, A. (2006). "Tick the Box Please": A Reflexive Approach to Doing Quantitative Social Research. Sociology, 40(6), 1191-1200.

Sachs, J. (2001). Teacher Professional Identity. Competing Discourses, Competing Outcomes. Journal of Education Policy, 16(2), 149-161.

Sica, A., \& Turner, S. (2005). (eds.). The Disobedient Generation. Social Theorists in the Sixties. Chicago: The University of Chicago Press.

Simbürger, E. (2009). Against and Beyond. For Sociology. A Study into the Self-understanding of Sociologists in England. (Unpublished doctoral dissertation). University of Warwick, Coventry, UK.

Simbürger, E. (2010). Critique and Sociology: Towards a New Understanding of Teaching as an Integral Part of Sociological Work. Enhancing Learning in the Social Sciences, 3(1). Retrieved from http://www.academia. edu/379801/Simb\%C3\%BCrger_E._2010._Critique_and_sociology_ towards_a_new_understanding_of_teaching_as_an_integral_part_ of_sociological_work_._Eliss_Enhancing_Learning_in_the_Social_ Sciences._Vol._3_1_Available_online_http_www.eliss.org.uk

Sloterdijk, P. (1984). Cynicism: The Twilight of False Consciousness. New German Critique (33), 190-206.

Smith, E. (2011). Teaching Critical Reflection. Teaching in Higher Education, 16(2), 211-223.

Stanley, L. (1992). The Auto/Biographical I: The Theory and Practice of Feminist Auto/Biography. Manchester: Manchester University Press.

Stanley, L. (2000). For Sociology. Gouldner's and Ours. In Eldridge, J., Maclnnes, J., Scott, S., Warhurst, C., \& Witz, A. (eds.). For Sociology. Legacy and Prospects. Durham: Sociologypress.

Stanley, L., \& Wise, S. (1990). Method, Methodology and Epistemology in Feminist Research Processes. In Stanley, L. (ed.). Feminist Praxis. Research, Theory and Epistemology in Feminist Sociology. New York: Routledge.

Stanley, L., \& Wise, S. (1993). Breaking Out Again. Feminist Ontology and Epistemology. London: Routledge.

Vujakovic, P., \& Bullard, J. (2001). The Ethics Minefield: Issues of Responsibility in Learning and Research. Journal of Geography in Higher Education, 25(2), 275-283.

Woolgar, S. (ed.). (1988). Knowledge and Reflexivity. New Frontiers in the Sociology of Knowledge. London: SAGE. 